Modern Asian Studies 52, 3 (2018) pp. 883-916. @C Cambridge University Press 2018 doi:10.1017/Soo26749X16001050

\title{
'A Hundred Per Cent Good Man Cannot do Politics': Violent self-sacrifice, student authority, and party-state integration in Bangladesh*
}

\section{BERT SUYKENS}

Conflict Research Group, Department of Conflict and Development Studies, Ghent University

Email:bert.suykens@ugent.be

\begin{abstract}
This article seeks to better understand political violence in Bangladesh. Analysing the case of student politics, the article enquires into the productive use of violence by student activists and leaders. It argues that student violence should not be considered as a breakdown of order or a sign of state fragility, but as a means of gaining access to party-state resources and patronage. Violence operates to mark out and maintain power relations between student groups and factions. Risktaking and the performance of self-sacrifice are important to delineate spaces of power and broker connections to potential political patrons. While actively engaging in political violence provides legitimacy within student hierarchies, victimhood provides a powerful means of publicly displaying one's commitment to a political party. Student public authority, while violent, is closely integrated in national political-party authority structures and, as a result, is intrinsically connected to the Bangladesh party-state. While it might seem counter-intuitive, this article argues that the use of political violence helps one to gain protection from the (party-)state.
\end{abstract}

\section{Introduction}

Student politics in Bangladesh is violent. This is often taken as a sign of its degeneration since the 1990 . Where students were previously considered to occupy the moral high ground in the struggle for

* The quote in the title is taken from an interview by the author with a senior Bangladesh Chhatro League (BCL) leader, University A. 
independence and in movements for the installation of democracy, since the return of democratic politics to Bangladesh in 1991, student political leaders are more and more often equated with criminals or even terrorists. ${ }^{1}$ It has been argued that violent politics-of which student politics forms a part-contributes to an increasingly fragile state. ${ }^{2}$ In contrast, and without wanting to glorify student violence, I think it productive to investigate the phenomenon in more neutral terms. Student violence in Bangladesh should not be considered purely criminal-indeed, labelling it thus obscures the productive use of violence for many student activists-nor should it be seen, more importantly, as a challenge to the state's monopoly over violence and thus as leading to state fragility. Rather, I argue that student violence can just as easily be interpreted as a sign of the enduring importance and resilience of the (democratic) state in Bangladesh, as many are willing to use violence and run the risk of being (lethally) wounded to gain access to the state and its scarce resources. It has remained the ultimate reference point for student politicians, as well as for a host of other violent actors, in the country. For (mostly male) student leaders and activists, (the capacity for) violence and the ability to organize or orchestrate it is a crucial tool to gain access to the resources of the state. I argue that the performance of risk and the public display of violent self-sacrifice play a crucial role in the integration of student activists and leaders in these party-state networks. While it might seem counter-intuitive, violence can help actors to gain protection from what I will call the Bangladesh party-state (see below).

My argument about contemporary Bangladesh is reminiscent of Karen Barkey's contention that non-state (bandit) violence should not be seen as a breakdown of the Ottoman state, as the bandit leaders 'perceived success as high-ranking positions in the Ottoman provincial administration and strove for incorporation'. ${ }^{3}$ While the

\footnotetext{
${ }^{1}$ Kamol, E. The tragedy of student politics in Bangladesh. The Star, 2 February 2010. Kawsar, M. H. Reign of terror. New Age Magazine, February 2012. Sultana, F. The chronicles of student politics: The current scenario. Star Campus, 6(o3), 22 January 2012.

${ }^{2}$ Fink, N. C. (2010). Bombs and ballots: Terrorism, political violence, and governance in Bangladesh. New York: International Peace Institute. Moreover, in 2008 Bangladesh was considered the 12 th most fragile states according to the Fund for Peace's Failed (later Fragile) States index. By 2015 this position had improved to 32 nd, although the country remains in the 'Alert' category.

${ }^{3}$ Barkey, K. (1994). Bandits and bureaucrats: The Ottoman route to state centralization. Ithaca: Cornell University Press, p. 195. See also: Barkey, K. (2008). Empire of
} 
'A HUNDRED PER GENT GOOD MAN GANNOT DO POLITICS' 885 student activists cannot be equated with Ottoman bandits, Barkey forces us to consider violence by non-state actors not as a sign of breakdown, but instead as an indicator of the potential power of the (central) state (or empire in her case). Rather than seeing the resulting state forms as fragile or failed (according to a certain ideal), it forces us to consider what type of state is produced in a context where actors use violence to gain access to it.

In looking at the relations between violent actors and the democratic Bangladesh state, I want to take a cue from a recent volume on 'violent democracies' in Latin America. In their introduction, the editors argue fruitfully that:

rather than understanding [...] endemic violence as simply a failure of democratic governance and institutions, we call attention to violence as an element integral to the configuration of those institutions, as a necessary component of their maintenance, and as an instrument of popular challenges to their legitimacy. ${ }^{4}$

This not to negate the often-problematic nature of such endemic violence, but to escape seeing violence simply 'as a reflection of anarchy, state breakdown, or the failure of the rule of law', and to investigate critically 'what particular forms of order are built up in polities in which multiple violent actors operate'. ${ }^{5}$ While Arias and Goldstein write about Latin America and do not claim any particular generalizability, I think theirs is a fruitful way to explore (student) violence in South Asia. As will be shown, student violence is closely tied to the democratic institutions of the Bangladeshi state and is indeed 'an element integral to the configuration of those institutions'. While it is quite obvious that student politics is intimately connected to the party system-in the past student organizations have operated simply as wings of political parties and are still closely associated with them-I will argue that student violence itself is a necessary tool to connect to the party-state.

The role of violence in making this connection cannot be understood without taking into account its performative qualities. In the field of student politics, authority emerges through the interaction between

difference: The Ottomans in comparative perspective. Cambridge: Cambridge University Press.

${ }^{4}$ Arias, E. D. and Goldstein, D. M. (2010). Violent pluralism: Understanding the new democracies of Latin America. In E. D. Arias and D. M. Goldstein (eds), Violent democracies in Latin America. Durham and London: Duke University Press, p. 4.

${ }^{5}$ Ibid., p. 26. 
performative violence and patronage. ${ }^{6}$ The ability to organize and control violence is crucial in attracting patronage from the partystate, while this patronage in turn allows successful student leaders to become patrons themselves of a faction of smaller leaders and activists. Crucially, it is all centred on gaining access to state resources. Even so, we should not directly equate authority within the (student-) political field with authority outside it. As I will argue, regarding serious violence as performative also means looking closely at the publics to whom these performances are directed.

While relatively naked struggles over the physical capacity to dominate partly help explain student violence in the research locations, risk and self-sacrifice are two central and related performative repertoires ${ }^{7}$ deployed to build authority within student hierarchies and attract the attention of party-state patrons. This element of self-sacrifice has a long history within the student movement in Bangladesh and has, through this historical example, become a powerful repertoire on which to draw. Self-sacrifice is actively sought, while risk is an everyday reality for student activists. Situations of risk might be transformed into sacrificial moments in which, through (the public display of) victimization, allegiance to student leaders or political party leaders is performed. As will be argued further, the engagement with violence has different functionalities for different sections of the political student body. And different types of violent engagements allow students to be differently deployed.

This article is based on fieldwork conducted in and around Dhaka ${ }^{8}$ in September 2011 and April 2012 and predominantly uses material collected from two campuses (which I call 'A' and 'B' universities). Interviews on student politics and violence were conducted with a host of student activists, hall residents (both neutral and political), and with

\footnotetext{
${ }^{6}$ See also: Klem, B. and Suykens, B. 'The politics of order and disturbance: Public authority, sovereignty, and violent contestation in South Asia' in this special issue.

${ }^{7}$ My use of repertoire here refers to: Tilly, C. (1993). Contentious repertoires in Great Britain, 1758-1834. Social Science History, 17(2), pp. 253-280.

${ }^{8}$ Dhaka - and certainly Dhaka University — can be said to play a particular role within the context of Bangladesh student politics. Students from the University have taken a central role in the major political movements discussed below and supply most of the leadership of the central committees of the student organizations. Besides, given that Dhaka plays a central role in the overall political organization of the country, Dhaka-based student leaders also have preferential access to political leaders. More research has to be conducted on student politics outside Dhaka, also taking into account urban-rural distinctions.
} 
a number of actors working on or in close vicinity to the campuses. ${ }^{9}$ Interview material from a third campus (' $\mathrm{C}$ ' University) is also used, but the analysis is mostly guided by the research that took place on the other two campuses. Fieldwork in March-April 2011 during a study of hartal organization in Chittagong, Bangladesh, has also informed my analysis here. ${ }^{10}$ This fieldwork material is supplemented with a collection of newspaper articles, which are very widely available, on student violence and its implications, and a sprinkling of political campaign material. My analysis of the latter material is informed by the fieldwork. Finally, an event database on political violence has been used to provide quantitative details on the distribution of political violence in Bangladesh.

The rest of this article will be organized as follows: I will start by (1) placing the findings of this study within a wider comparative (South Asian) perspective, (2) provide a conceptualization of the Bangladesh state as a party-state, and (3) give a short overview of the distribution of political violence in Bangladesh and the role of student organizations in this violence. Then we will turn our attention to the role of sacrifice and risk-taking in student violence, and (4) provide a functional history of the role of student movements in the formation of (democracy in) Bangladesh, with particular attention paid to the role of student sacrifice in these movements. Next we will consider the field data (5) to explain the role of inter-party rivalry and student violence, (6) analyse factional violence and introduce a specific case study on the role of student violence on one campus, and (7) show how this violence is closely connected with the conscious use of particular repertoires and performances of risk, self-sacrifice, and victimhood. Finally, (8) I will connect these different elements and argue that violence by student activists, and their willingness to take risks, play a crucial role in gaining access to state patronage, both during their student days and beyond. Violence and protection turn out to be recursively constituted. And student activists' violence should

\footnotetext{
${ }^{9}$ Because of the controversial nature of the subject, names of respondents have been removed. I will indicate their position within the BCL, Jatiyatabadi Chhatro Dal (JCD), or outside these organizations. The names of the three campuses where the research was conducted have also been withheld, although the knowledgeable reader will probably be able to identify them.

${ }^{10}$ For details see: Suykens, B. and Islam, A. (2013). Hartal as a complex political performance: General strikes and the organisation of (local) power in Bangladesh. Contributions to Indian Sociology, 47(1), pp. 61-83.
} 
thus not be seen as a sign of the slow breakdown of the Bangladeshi state, but could be interpreted as showing its resilience.

\section{Bangladesh student violence in comparative perspective}

The research shows that the student violence discussed here is of a distinctive nature compared to more dominant communal violence and goonda politics in India, a point we will come back to in later sections of the article. First, however, studies of communal violence in India have also shown convincingly the multiple interrelations between politicians, state bureaucracies (including police), and violence specialists in organizing communal violence. ${ }^{11}$ In effect, recent work on the topic argues that we can only understand its robust nature by taking a relational view of this type of violence, and analysing how it is rooted in everyday interactions between state actors (politicians, administration, the police), violence specialists, and the general population. ${ }^{12}$

However, unlike communal violence, in which crowd participation is one of the central elements requiring explanation, ${ }^{13}$ student political violence predominantly engages the political class itself. Those outside student politics are, to a large extent, not drawn in; most casualties are also student activists. Secondly, student activist respondents share a highly instrumentalist view of the violence used. This departs from research on both communal violence and wider patterns of goonda violence on which interesting research has been conducted on the cosmologies of violent actors as embedded in particular types of violent masculinities, for example that associated with wrestling. ${ }^{14}$

\footnotetext{
${ }^{11}$ See, for example, Brass, P. R. (1997). Theft of an idol: Text and context in the representation of collective violence. Princeton: Princeton University Press; Brass, P. R. (2003). The production of Hindu-Muslim violence in contemporary India. Seattle and London: University of Washington Press; Hansen, T. B. (2001). Wages of violence: Naming and identity in postcolonial Bombay. Princeton and Oxford: Princeton University Press; Das, V. (2006). Life and words: Violence and the descent into the ordinary. Berkeley: University of California Press; Sen, A. (2007). Shiv Sena women: Violence and communalism in a Bombay slum. London: Hurst and Company.

${ }^{12}$ Berenschot, W. (2011). Riot politics: Hindu-Muslim violence and the Indian state. London: Hurst and Company.

${ }^{13}$ Ibid.

${ }^{14}$ Peabody, N. (2009). Disciplining the body, disciplining the body-politic: Physical culture and social violence among North Indian wrestlers. Comparative Studies in Society and History, 51(2), pp. 372-400; Michelutti, L. (2014). Kingship without kings in
} 
'A HUNDRED PER GENT GOOD MAN GANNOT DO POLITICS' 889 While more research in Bangladesh should be conducted on how particular cosmologies relating to (mastaan) violence are present in public culture-for instance, in Dhallywood productions or as part of ha do do (Kabaddi, the national game of Bangladesh) masculinities ${ }^{15}$ student activists did not frame their engagement in violence in these terms. $^{16}$

In the literature mentioned above an ideological distinction between groups-such as Hindu-Muslim or Yadav-Other castes-forms part of the cosmological imagination of righteous violence; here such ideological distinctions are limited in the type of student violence that is discussed. ${ }^{17}$ The lack of ideological differences between the Awami League (AL) and the Bangladesh Nationalist Party (BNP) has been lamented regularly and, as a lot of student violence is also factional, the ideological distinctions between the two parties are hardly of a nature on which to base a distinct cosmology. While student activists strongly adhere to their party's version of Bangladesh political history, for example_-stressing either Sheikh Mujib's or Ziaur Rahman's central role in the making of Bangladesh-both sides in student violence share, to a large extent, the same understanding of what politics entails and are internally divided on similar class lines. As such, student politicians, with their highly instrumental use of violence as a way to access state resources, and lacking strong ideological commitment, are exemplary of a wider political class. It has been argued, for example, that during the regime of Ziaur Rahman, people joined his party (the BNP) 'not because they were attracted by the ideology [...] of the party, but for the sake of power, office

northern India. In A. Piliavsky (ed.), Patronage as politics in South Asia. Delhi: Cambridge University Press, pp. 283-302.

${ }^{15}$ Thanks go to Aynul Islam for interesting insights on how this might play out.

${ }^{16}$ While a purpose of this article is to highlight the functionality of violence for student activists, we should be aware of discipline-specific preoccupations. Also, in the Indian literature on communal violence and goonda politics, political scientists have often taken a more instrumentalist stance (see, for example, Brass, The production of Hindu-Muslim violence; Berenschot, Riot politics), while anthropologists (including Hansen and Michelutti) have stressed more the importance of specific cosmologies. Both interpretations supplement each other and are hardly incompatible. It is this kind of discussion from which the study of political violence in Bangladesh could also benefit.

${ }^{17}$ Violence between Chhatro League and the Jamaat-e-Islami's Islami Chhatro Shibir does sometimes contain these stronger ideological distinctions. 
and patronage'. ${ }^{18}$ This is a criticism that has been repeated for other Bangladesh regimes as well. ${ }^{19}$

Finally, the implication of students and student movements in violence is not uncommon in South Asia. In Bangladesh a number of researchers have focused on student politics and associated violence. ${ }^{20}$ Arild Engelsen Ruud has investigated the way mastaans (violent strongmen engaged in the protection and extortion business) emerge out of student politics; ${ }^{21}$ Morten Koch Andersen's (unpublished) $\mathrm{PhD}$ thesis provides an interesting overview of the student politics of Dhaka University and is also interested in similar questions of mobilization and antagonism as well as individual aspirations within the framework of organized student politics. ${ }^{22}$ In Pakistan, the likes of Oskar Verkaaik ${ }^{23}$ and Laurent Gayer ${ }^{24}$ have analysed the involvement of students in urban violence in Karachi. Indeed, the influential Muhajir Qaumi Movement (MQM) came out of political student activities. ${ }^{25}$ In northeast India, the role of student organizations in violent activities is also very obvious. Many student groups have engaged in violence themselves and have close linkages with, or form the basis for, the organization of rebel movements in the area. ${ }^{26}$ Here, access to the state is also an important element, as members

${ }^{18}$ Hossain, G. (1988). General Ziaur Rahman and the BNP: Political transformation of a military regime. Dhaka: University Press Ltd., p. 26.

${ }^{19}$ See, for example, Jahan, R. (2005). Bangladesh politics: Problems and issues. Dhaka: University Press Ltd.

${ }^{20}$ A short note about the relation between the work on student politics in Bangladesh mentioned below and this article: this article was first presented, including its main argument, at the European Conference of Modern South Asian Studies in Lisbon in 2012. As such, the argument and article were developed independently from the mentioned work. That being said, the arguments presented here strongly concur with the views of the authors mentioned below. This I take as a sign of the robustness of the findings. I will indicate these concurrences in footnotes.

${ }^{21}$ Ruud, A. E. (2014). The political bully in Bangladesh. In Piliavsky (ed.), Patronage as politics, pp. 303-325.

${ }^{22}$ Andersen, M. K. (2013). The politics of politics: Youth mobilization, aspirations and the threat of violence at Dhaka University, $\mathrm{PhD}$ thesis, University of Copenhagen. See also: Andersen, M. K. (2016). Time-use, activism and the making of future. South Asia: The Journal of South Asian Studies, 39(2), pp. 415-429.

${ }^{23}$ Verkaaik, O. (2004). Migrants and militants: Fun and urban violence in Pakistan. Princeton: Princeton University Press.

${ }^{24}$ Gayer, L. (2007). Guns, slums, and 'yellow devils': A genealogy of urban conflicts in Karachi, Pakistan. Modern Asian Studies, 41 (3), p. $5^{1} 5^{\text {. }}$

${ }^{25}$ Verkaaik, Migrants and militants, pp. 6o-63.

${ }^{26}$ See, for example, Baruah, S. (2003). India against itself: Assam and the politics of Nationality (2nd edn). New Delhi: Oxford University Press. 
'A HUNDRED PER GENT GOOD MAN GANNOT DO POLITICS' 891 of student groups can become elected leaders after peace deals have been reached. ${ }^{27}$

\section{The operation of the party-state in Bangladesh}

The nature of the Bangladesh state has proven to be quite elusive and few authors have discussed it head on. ${ }^{28}$ As already stated in the Introduction to this special issue, this elusiveness of the state has haunted the social sciences in general. Rather than recount the debate again here, I want to provide some pointers as to how the operation of the Bangladesh state could be understood. Crucial in this is the relation between the state and the party regime that controls it. In an insightful report on the state of governance in Bangladesh, it has been argued that Bangladesh should be considered a 'partyarchy':

In the Bangladeshi system where the winning party enjoys the monopoly of power for the duration of their electoral term, $[\ldots]$ the ruling party and its innermost circle have emerged as the unrivalled centre of political power. This innermost circle has de facto command over the entire party, legislature, parliamentary committees, procurement policies, development allocations, bureaucracy and law and order enforcement agencies. ${ }^{29}$

Drawing on this notion of partyarchy, I would describe Bangladesh as a party-state. While this term has its roots in the analysis of autocratic political regimes in West Africa, ${ }^{30}$ it helps to pinpoint the close association between party and state. ${ }^{31}$

Historically, this association has taken different forms. AL's role in the independence struggle led to a vast electoral victory in the first national elections. Yet AL's total control and the preferential treatment of its supporters in the following years created much resentment. To counter the protest, but also to better control

${ }^{27}$ See, for example, Vandekerckhove, N. (2010). No land, no peace: Dynamics of violent conflict and land use in Assam, India, PhD thesis, Ghent University.

${ }^{28}$ See, for example, Khondker, H. H. (2004). Class and state in Bangladesh: Political economy of an authoritarian democracy. Journal of Bangladesh Studies, 6(1), pp. 20-34.

${ }^{29}$ Hasan, M. (ed.) (2006). The state of governance in Bangladesh 2006: Knowledge, perceptions, reality. Dhaka: Centre for Governance Studies, p. 20.

${ }^{30}$ Zolberg, A. R. (1 966). Creating political order: The party-states of West Africa. Chicago: Rand McNally and Company.

${ }^{31}$ For a full development of this argument and its historical genesis, see: Suykens, B. (forthcoming) The Bangladesh party-state: A diachronic comparative analysis of party-political regimes. Commonwealth E Comparative Politics. 
factionalism, corruption, and unruliness in its own ranks, Sheikh Mujib installed what could be considered a classical type of partystate, with BAKSAL becoming the one-party vehicle for rule. When Ziaur Rahman came to power, he tried, with a different type of partystate, to put a more civilian face on his erstwhile military regime. He launched a political party, the $\mathrm{BNP}$, as a vehicle to organize this transformation into what can be called a form of democratic authoritarianism. ${ }^{32}$ Ershad would make a similar move by organizing the Jatiya Party.

Since 1991, the Bangladesh party-state has taken on a democratic form in which BNP- and AL-led alliances have alternated in power (with the exception of the current AL regime, in power since 2014). Most student actors interviewed seemed to take it as a given that a period of AL rule would be followed by a period of the BNP being in power. This means that they also count on this when committing violence. Many of our respondents commented that they have to time their actions correctly, depending on whether they want to benefit from them immediately, when their party comes to power, or when it returns to power after a stint in opposition. When in power, each party has virtually taken over the state. As a result, access to the party translates into access to the state. This, of course, also means that a change in party regime leads to quite a number of changes, for instance in who is recruited (for example, in universities), who serves in crucial posts, who gets business contracts, and so forth. Moreover, this also permeates other sectors of public life which are not at first sight closely related to the state, like business and market associations or, as we will discuss in more detail in the next sections, student hall committees. It also determines to quite some extent who will be able to capture or control valuable resources, like (public) land.

We thus agree that the line dividing state and society is never stable and that it is not 'the perimeter of an intrinsic entity, which can be thought of as a free-standing object or actor'. ${ }^{33}$ Yet this 'line drawn internally'34, in which party and state are never completely overlapping, also produces a number of outsiders. The political student organizations, although highly integrated in their respective parties,

\footnotetext{
${ }^{32}$ For an overview of the literature on this type of regime, see: Brancati, D. (2014). Democratic authoritarianism: Origins and effects. Annual Review of Political Science, $17(1)$, pp. 313-326.

${ }_{33}$ Mitchell, T. (1991). The limits of the state: beyond statist approaches and their critics. The American Political Science Review, 85 (1), p. 90.

${ }^{34}$ Ibid., p. 90.
} 
'A HUNDRED PER GENT GOOD MAN GANNOT DO POLITICS' 893 are just such an example. Moreover, as we will show in the next sections, individual student leaders and activists are continuously vying for position within student organizations as a way of brokering access to the party-state. Before we start to explicate the role of political violence in these efforts, we first want to provide a short overview of political violence in the country to better situate student violence.

\section{Political (student) violence in Bangladesh: basic data}

Student violence should be understood within a wider context of political violence in Bangladesh. According to the data recorded in a recent event database on the topic, ${ }^{35}$ more than 126 ,ooo people were wounded and over 2,40o killed in political violence between 2002 and 2013. They belonged to quite a number of political groups, including political parties, their wings (including student wings), but also to rebel and Islamist (terrorist) groups. It is quite clear from the data that AL and BNP, and their wings, are the most active forces when it comes to political violence. The data show that most of the violenceand certainly that involving the two main parties-is non-lethal, but that some groups are more prone to lethal violence, including leftist rebel groups and Islamist groups, with their members often being killed in skirmishes involving law enforcement agencies. Regionally, Dhaka is, as expected, the most violence prone: around 15 per cent of all events and wounded come from Dhaka district. In the period studied, 2006 and 2013 were by far the most violent years, both of which preceded the run-up to elections, although the electoral scenario alone cannot explain the violence. ${ }^{36}$

If we zoom in on student organizations (see Table 1), we again see the dominance of AL's Bangladesh Chhatro League (BCL) and the BNP's Jatiyatabadi Chhatro Dal (JCD), with Jamaat-e-Islami's Islami Chhatro Shibir relatively less engaged. BCL was involved in over 2,200 events of political violence between 2002 and 2013, JCD in more than $\mathbf{1 , 5}$ oo, and Shibir in more than 880. Respectively this corresponds

\footnotetext{
${ }^{35}$ Suykens, B. and Islam, A. (2015). The distribution of political violence in Bangladesh (20O2-2OI3). Ghent: Conflict Research Group.

${ }^{36}$ In 2006 actions against left-wing insurgents led to quite a number of lethal casualties, while the violence in 2013 was also, to a large degree, associated with the protests against the war crimes tribunal.
} 
TABle 1.

Involvement of major student organizations in political violence. ${ }^{37}$

\begin{tabular}{|c|c|c|c|c|c|c|}
\hline & \multicolumn{2}{|c|}{ Events } & \multicolumn{2}{|c|}{ Wounded } & \multicolumn{2}{|c|}{ Lethal casualties } \\
\hline & Number & $\%$ & Number & $\%$ & Number & $\%$ \\
\hline $\begin{array}{l}\text { Bangladesh Chhatro } \\
\text { League }\end{array}$ & 2,210 & $15.6 \%$ & ${ }^{1} 5^{, 1} 5^{1}$ & $12.0 \%$ & 121 & $5.0 \%$ \\
\hline $\begin{array}{l}\text { Jatiyatabadi Chhatro } \\
\text { Dal }\end{array}$ & 1,553 & $11.0 \%$ & 12,043 & $9.5 \%$ & 99 & $4.1 \%$ \\
\hline $\begin{array}{l}\text { Islami Chhatro } \\
\text { Shibir }\end{array}$ & 887 & $6.3 \%$ & 8,483 & $6.7 \%$ & $9^{2}$ & $3.8 \%$ \\
\hline
\end{tabular}

to 15.6 per cent, 11 per cent, and 6.3 per cent of all violent events in this period. Over ${ }_{1} 5$, Ooo people were wounded in events in which BCL members participated ( 12 per cent of the total); this figure was over 12,000 for the JCD (9.5 per cent of the total), and over 8,400 for Shibir (6.7 per cent of the total). Lethal casualties were relatively limited, with 121 people killed in events in which BCL members were involved ( 5 per cent of the total number of lethal casualties); the figures were 99 (or 4.1 per cent) for JCD and 92 (or 3.8 per cent) for Shibir. ${ }^{38}$

Each of these groups engages with a number of different groups, but, certainly for members of the BCL and JCD, violence is concentrated on other student groups. Shibir has been involved in a substantial number of clashes with law enforcement agencies. Crucially for this article is the fact that both the BCL and JCD see more factional than inter-group violence. Over 40 per cent of BCL-related and over 30 per cent of JCD-related violence is factional. In comparison, inter-group violence in which both the BCL and JCD engage each other accounts for only over 20 per cent for each group.

Regionally, Dhaka remains the most important hub of student politics and also the most violent centre of student political activity (see Table 2). However, much more research should be undertaken in other important university towns as student violence in some districts (like Rajshahi or Sylhet) accounts for more than half of all violent incidents.

\footnotetext{
${ }^{37}$ For more details on the methodology behind these numbers, see: Suykens and Islam, The distribution of political violence.

${ }^{38}$ These numbers should not simply be added up to get the total number of casualties in student-related violence. As more than one actor participated in most events, multiple response sets were used to calculate these numbers.
} 
'A HUNDRED PER GENT GOOD MAN GANNOT DO POLITICS' 895

TABLE 2.

Distribution by district of campus and student violence (top ${ }_{5} 5$ districts). ${ }^{39}$

\begin{tabular}{|c|c|c|c|c|c|c|}
\hline & \multicolumn{3}{|c|}{ On campus violence } & \multicolumn{3}{|c|}{$\begin{array}{l}\text { Violence involving (one } \\
\text { or more) student groups }\end{array}$} \\
\hline & Events & $\begin{array}{l}\% \text { of } \\
\text { district } \\
\text { violence }\end{array}$ & $\begin{array}{l}\% \text { of } \\
\text { campus } \\
\text { violence }\end{array}$ & Events & $\begin{array}{l}\% \text { of } \\
\text { district } \\
\text { violence }\end{array}$ & $\begin{array}{l}\% \text { of } \\
\text { student } \\
\text { violence }\end{array}$ \\
\hline Dhaka & 1,082 & $31.9 \%$ & $34 \cdot 3 \%$ & 1,371 & $40.5 \%$ & $25.8 \%$ \\
\hline Rajshahi & $35^{1}$ & $43.8 \%$ & $11.1 \%$ & $44^{2}$ & $55.2 \%$ & $8.3 \%$ \\
\hline Chittagong & 228 & $22.7 \%$ & $7.2 \%$ & 423 & $42.0 \%$ & $7.9 \%$ \\
\hline Sylhet & 149 & $26.7 \%$ & $4 \cdot 7 \%$ & 294 & $5^{2.6 \%}$ & $5 \cdot 5 \%$ \\
\hline Narayanganj & 147 & $21.9 \%$ & $4.7 \%$ & 132 & $19.7 \%$ & $2.5 \%$ \\
\hline Kushtia & 121 & $27.6 \%$ & $3.8 \%$ & 145 & $33.1 \%$ & $2.7 \%$ \\
\hline Khulna & 104 & $23.5 \%$ & $3 \cdot 3 \%$ & 123 & $27.8 \%$ & $2.3 \%$ \\
\hline Mymensingh & 93 & $25.8 \%$ & $3.0 \%$ & 117 & $32.4 \%$ & $2.2 \%$ \\
\hline Barisal & 63 & $15 \cdot 4 \%$ & $2.0 \%$ & 143 & $34.9 \%$ & $2.7 \%$ \\
\hline Comilla & 59 & $13.3 \%$ & $1.9 \%$ & 134 & $30.3 \%$ & $2.5 \%$ \\
\hline Rangpur & 59 & $22.3 \%$ & $1.9 \%$ & 66 & $25.0 \%$ & $1.2 \%$ \\
\hline Bogra & 53 & $11.6 \%$ & $1.7 \%$ & 101 & $22.1 \%$ & $1.9 \%$ \\
\hline Noakhali & 44 & $8.7 \%$ & $1.4 \%$ & 135 & $26.6 \%$ & $2.5 \%$ \\
\hline Dinajpur & 40 & $19.3 \%$ & $1.3 \%$ & 62 & $30.0 \%$ & $1.2 \%$ \\
\hline Jessore & $3^{2}$ & $9 \cdot 5 \%$ & $1.0 \%$ & 70 & $20.7 \%$ & $1.3 \%$ \\
\hline
\end{tabular}

\section{Student movements, violent sacrifice, and the formation of democratic Bangladesh}

When discussing the role of student politics in Bangladesh, student leaders and activists will most commonly start by explaining the heroic role played by the student movement within major national (political) movements. They extol the sacrifices made by students as leaders of nationalist and pro-democracy struggles. The historic role of student activism has been relatively well documented, and a number of public monuments have been erected at central locations (for example, around the Dhaka University campus) as public memorials of student struggle and sacrifice. ${ }^{40}$

Sheikh Mujibur Rahman, the leader of the independence movement and first head of state and prime minister of independent Bangladesh, started his career as a student activist and leader, first for the

\footnotetext{
${ }^{39}$ For more details on the methodology behind these numbers, see: Suykens and Islam, The distribution of political violence.

${ }^{40}$ For an overview, see: Ali, S. M. (2010). Understanding Bangladesh. New York: Oxford University Press, pp. 271-284.
} 
Muslim Students League and later the AL-affiliated BCL, becoming a 'role-model' of 'agitational activism' for later generations of student leaders. Like many student activists and leaders after him he was eventually expelled from Dhaka University. ${ }^{41}$

The Language Movement of $195^{2}$ was a foundational moment in student activist history. (Violent) activism, including the possibility of sacrifice and martyrdom for one's political cause, became enshrined in the student political repertoire. During the agitation to have Bengali recognized as one of the state languages of undivided Pakistan, four students were killed by (provincial Bengali) police. They received almost immediate recognition as martyrs of the Bengali, and later Bangladeshi, national cause. They are remembered by a central Shaheed Minar ('Martyr's Monument') in the vicinity of Dhaka University and Dhaka Medical College, and there are many copies around the country.

The student movement took a leading role in the struggle for independence, involving violent confrontations with the police in the late 1960 s which led to students losing their lives in the process. They continued the struggle, first campaigning for AL candidates in the 1970 elections and then, the following year, forging the path for independence, by, for example, designing the new flag, settling on the national anthem (the Tagore song Amar Sonar Bangla), and leading a non-cooperation movement. After Pakistan's military repression during Operation Searchlight, students joined different groups of freedom fighters, again becoming martyrs for independent Bangladesh.

The post-independence period saw much fracturing of the student body, with the BCL (supported by AL) and JCD (supported by the BNP) emerging as the most powerful student bodies, and the Islami Chhatro Shibir (supported by Jamaat-e-Islami) and a number of leftwing student bodies vying for position, their strength depending on time and place. The joining of the rival BCL and JCD under the banner of the All-Party Students Unity is often considered to be of central importance in the success of the anti-Ershad movement for the restoration of democracy at the beginning of the 199os. Student activist and leaders, as well as ordinary students, engaged in a number of violence clashes with the police, leading to many being wounded and one student activist dead. After Ershad also lost the support of the military, he finally handed over power, after which democratic

${ }^{41}$ Ibid., p. 273. 
'A HUNDRED PER GENT GOOD MAN GANNOT DO POLITICS' 897 elections were held and the BNP formed the first democratically elected government in 1991 .

This historic role of the student movement in gaining Bangladesh's independence and in the restoration to democracy continues to provide legitimacy and authority to student politics. Although the current state of student politics is often lamented (for example, in the opinion pages of major newspapers), the student movement retains part of its aura of being a major force that led movements of national interest in the past-but this also informs the perception that it has the potential to lead such movements in the future. Those who lament the violence associated with student activism sometimes tend to downplay how violent it was in the past. In earlier phases, it was deemed legitimate and as a necessary element of the struggle against political oppression (first by the Pakistan state and later by autocratic rulers like Ershad). The current role of violence in student politics, while serving different goals from that which took place during previous national movements, should not be completely disconnected from the historic role of violence. Historically the students' capacity for violence was a notunimportant part of their usefulness in national movements. This is maintained in the current democratic era, and different respondents argued that this force could be redeployed if necessary to serve the national interest.

Student leaders draw upon this history to legitimize the important place student politics has in Bangladesh and to validate their own role as public authorities. As such, the historic martyrdom of student activists is operationalized in a quite different context, where student politics is often seen as a way to access power and resources, rather than as a disinterested sacrifice for the nation. However, historic notions of martyrdom and sacrifice remain crucial repertoires for student activists, as I hope to show more clearly in the next sections. In the new context of inter-party and factional rivalry, the legacy of sacrifice-this time for the party (faction) - continues to play a discursive role, but also, as will be seen in the later sections of the article, is actively sought by student activists wanting to claim their place within political organizations.

\section{Inter-party rivalry and student politics}

If the BNP comes to power in two years, I have to disappear from campus, or maybe go underground. (Middle-level BCL activist, University A) 
As mentioned above, mainstream student politics in Bangladesh centres on the rivalry between the two main political parties: the AL and BNP, with the BCL associated with the former, and the JCD with the latter. Both have a national committee, regional sub-committees, and units in almost all universities and colleges. Our research showed that the most basic, but also most crucial, level of organization was the student halls (dorms). Here, a hall president and a secretary, who lead a hall committee which decides on most matters pertaining to hall organization, share power. President and secretary also control the student organization's cadres.

Bangladesh politics is dominated by a 'winner takes all' mentality, and the same is true of student politics:

After every national election, the first thing the student wing of the winning party does is take control of all the educational institutions from the losing party cadres $[\ldots]$ When the winning student wing [...] took over the campuses, sometimes it didn't even take any fighting for rivals to exit, they left voluntarily. Where this unwritten code of conduct was not followed voluntarily, $[\ldots]$ cadres [from the party in power] kicked them out, just as they had been purged $[\ldots]$ after the [previous] elections. ${ }^{42}$

The student group affiliated with the ruling party controls the campus. At the time of my research, the AL (and thus the BCL) was in power. This also means that known (and certainly notorious) activists from the opposition party cannot visit the campuses. ${ }^{43}$ The quote at the beginning of this section reflects well what this entails for individual cadres, while at the same time stressing the sacrifices that one might have to be willing to make to be active in student politics. Violence is mostly used to stake out claims. After elections, the winning party's student organization takes over the campus and, most importantly, the halls. We heard different stories about political activists being beaten and their possessions looted and burned. Both sides of the student

\footnotetext{
${ }^{42}$ Kamol, The tragedy of student politics.

${ }^{43}$ Consequently, because they are off campus and cannot follow classes or take exams for a number of years if their party is not in power, political activists often have extended university careers. Moreover, student leaders tend to artificially prolong their student days, by failing exams or taking additional programmes of study. This is one of the reasons why Sheikh Hasina, the leader of AL, recently decided, in a move to clear the party's involvement in the negative aspects of student politics, to put an age limit of 28 for membership of the BCL. JCD, with many of its top leaders over the age of 40, is currently debating a similar move. The JCD Central Committee appointed in September 2012 included members over the age of 40.
} 
'A HUNDRED PER GENT GOOD MAN GANNOT DO POLITICS' 899 movement considered this normal practice, and it was not something that was heavily resented.

After rule has been established, violence is used to maintain it, which means not allowing known (and active) members of the rival group to enter the campus, even for classes. If rival student leaders dare to enter the campus they are often beaten and chased away. As shown below, while this is a simple enough exercise for the group aligned with the party in power, it also provides some opportunities for the opposition student group to show its commitment to its (party) leadership. Indeed, the most explicit examples of the public display of self-sacrificial performativity can be found in instances of inter-party violence (for an example see below). It banks on an understanding of politics that is informed by public hostility between both parties, exemplified by adverse relations between the 'battling begums', 44 AL's Sheikh Hasina and the BNP's Khaleda Zia, who last met (officially) in 2009. Inter-party student violence is its most expected manifestation and can be easily understood in the context of confrontational politics in Bangladesh. Securing the campus from opposition rivals is a sine qua non for any student group or leader, even more so in Dhaka. Yet, the violence within the student groups, where such political cosmological rivalry seems to be absent, demands more attention.

\section{Intra-party violence: factional clashes}

Violence means power. (JCD leader, University C)

Factional violence is at first sight more surprising than inter-party violence, as it pits activists within the same party against one other. But, as I will show, factional violence too plays a central role in gaining access to the party-state. I will argue that this type of violence is crucial when establishing public authority in and around campuses, and to gain access to the state. Indeed, this is only possible when successfully engaging in factional violence.

In theory, all student activists from the party in power, at all the different levels of the student organization, have a privileged position in relation to the party. However, this does not explain how this link is constituted, how specific connections are made, and who takes

\footnotetext{
${ }^{44}$ Battling Begums: Sheikh Hasina reaches out to grieving Khaleda Zia; turned away from the gates, The Indian Express, 25 January 2015 .
} 
precedence over whom. Fieldwork undertaken among student activists makes it very clear that there are multiple factions and that only a limited few have a privileged position vis-à-vis the party leadership. Creating these links is thus a crucial element in maintaining one's importance as a student activist. And it is in this sense that violence becomes crucial. The control over violence becomes a marker to signal one's importance as a privileged partner of the party in power. This then opens the way for state patronage both during and after one's student days.

This is perhaps most obvious when the balance of power between different factions within the ruling organization is undecided or when it is unclear how power relations within the student body are organized. This, for instance, is the case when the 'mother' party initially comes to power. The halls have to be taken over and positions decided. This often results not only in inter-party clashes, but also in factional violence. Yet, as the case study discussed next shows, this lack of clarity can also occur in the middle of a period of rule.

\section{'Nobody has a position'}

There have been many clashes the last few months. They are many groups. And they are fighting for power. It is power politics. ('Non-political' student, closer to left-wing parties, A University)

One such example of an undecided situation forms the central element in student violence in one of the universities studied. The university where this fieldwork took place was selected because it had been the site of endemic, ongoing factional clashes for a number of years. This has led to a relatively high number of severely injured students, the occasional deadly casualty, and the regular expulsion of student leaders and their supporters from the campus, both temporarily and permanently.

As mentioned above, when trying to understand student violence, the halls are always a useful starting point as they comprise both the most basic level of student organization and are also the stronghold of campus student leaders. As such they mirror the factional divisions on the campus. Every hall has a committee where the holders of the two most important positions - those of hall president and hall secretaryare most often also the leaders of two different factions, vying for influence within the hall. Similarly, the different halls of the campus 
are also divided between the factions of the president and secretary of the university committee of the student organization:

There always were two camps in the university, one comprising B. Hall, M. Hall and the extension of A. Hall, the other comprising of BH Hall, the main building of A. Hall, K. Hall and S. Hall. If the president [from the university student committee] came from one camp, the secretary had to come from the other. But now we are trying to convince the leadership that this is no longer necessary. The leadership in the other camp halls is not strong. We would be able to control the campus. (BCL faction leader, A University)

The existence of committees at both the hall and the university levels means that there are a large number of student activists 'positions' available, on both a junior-for example, hall committee member-and a senior - for example, campus secretary-level. While it enables different factions to gain positions within the political student structure, it also stimulates the existence of these different factions, all vying for position.

Violence plays a role at all these different levels. It is often the outcome of a previous cycle of violence, aimed at controlling specific halls or the campus as a whole. When asked about the reasons for current violence on campus, the answer was fairly uniform across factions, halls, and parties:

The violence happened because there is no committee; so there are many groups and factions, in different halls who want to have the power. (Senior BCL leader, A University)

Or,

Violence happens because there is no committee, so there is no authority to keep everybody in check. Many leaders want to show their power and increase their position, because they want a place in the committee. (Middle-level BCL cadre, A University)

Violence has a crucial signalling function. Most respondents agreed that a committee was most important because it established authority, it fixed hierarchies, and made it less necessary to commit further violence to consolidate one's position. A good student leader, with a high position on the university committee, should also have the ability to keep the campus quiet and to keep violence in check. But, as the different positions were not allocated, it was crucial for those aiming for a place on the committee to show their strength vis-à-vis potential competitors. This is where the second quote above is crucial, as this 
mid-level BCL cadre made a clear connection between violence, the show of power, and a place on the committee.

The struggle for a 'position' has numerous functions. As I will argue in the next section, its most important function is gaining access to the state. Yet, crucially connected to this is that a position gives you access to supporters:

Without a position it is difficult to sustain leadership. It is difficult to convince first year students. Because over two years if the BNP comes to power, it will be difficult. But how can I convince them if I cannot offer anything? (Senior BCL leader B, A University)

\section{Or,}

Without the committee nobody has a position. It is difficult to have power, without a position. It is difficult for the supporters too, because we cannot sustain them easily. Even so, if something happens, we have to take care of them. (Middle-level BCL cadre, A University)

Although these quotes appear to be very similar, there is an interesting dissimilarity between them. While the former indicates that a position will attract supporters, because a leader is able to offer benefits, the latter points to the importance of sustaining supporters even when there is no committee. Closely associated is that the ability to commit violence in the absence of a committee shows the strength of a particular student leader. ${ }^{45}$ Having followers who are willing to commit violence in your name, even if the outcome is unclear, clearly shows off the specific student leader's organizational power and as such his potential value. ${ }^{46}$

Moreover, and crucial for this special issue, both these quotes indicate how violence plays a pivotal role in the provision of patronage by student leaders. Their authority and control over a faction of supporters necessitates the ability to 'offer' them something, to be able to take care of them. As will be discussed in the next section, this in turn makes violence highly performative in the efforts of student leaders to in turn attract patronage to distribute to their supporters.

\footnotetext{
${ }^{45}$ See also: Ruud, A. E. (2010). To create a crowd: Student leaders in Dhaka. In P. Price and A. E. Ruud (eds), Power and influence in India: Bosses, lords and captains. New Delhi: Routledge, pp. 70-95.

${ }^{46}$ For a similar example for the Chhatro Dal, where factional violence was used to settle a hierarchy, see: Andersen, Time-use, activism and the making of future, pp. 203-212.
} 
As mentioned in the introduction, perceiving serious violence as performative also means looking closely at the publics. Here the analytical distinction between authority and power (using a Weberian framework) derived from (organizing) violence appears as an outcome of different appreciations of multiple publics to the spectacle of violence. For those within the student group, gaining dominance through violence is legitimizing. Violence is seen as a legitimate means to gain dominance in a campus and, to put it bluntly, those coming out on top (after multiple rounds of violence) have the authority to control the campus and its resources. Authority, however, is contingent on being able to also ward off violent challenges to this domination. The same holds true for potential patrons for which the capacity to organize (but also subdue) violence is a sign of authority. Very successful student leaders are able to control violent resources to such an extent that factional violence is highly limited. In our case, the struggle was to gain dominance in a committee which had yet to be established. After this round of violence, and with positions decided on, it was generally expected that peace would return to the campus, with less aggressive forms of interaction-like showdowns-occurring. However, as events in 2014 show, the accommodation of different factions could lead to continued violence in the cause of establishing this supremacy, resulting in new cycles of violence. ${ }^{47}$ Importantly, and returning to the issue of publics, many respondents outside the BCL-JCD (including those within, for example, left-wing student organizations) would rather argue that only power and not authority emerged from this (factional) violence. The ability to employ violence was seen as a way to achieve more naked forms of domination, simply by showing the supremacy of certain groups, rather than considering violence as a legitimate way to access power. This sentiment seems to be shared rather widely, as can be seen from the (middle-class) press, which condemns this violence and considers it as a breakdown of legitimate order-making.

\section{Risk and the iconography of sacrifice}

As political students we take a lot of risks. It is the risk for your life even. You know [...] students were thrown off a roof a few years ago. Members of a rival group [of BCL] attacked us here in 2010 . Our blood, my blood lies here

${ }^{47} 16 \mathrm{JU}$ Chhatra League men expelled, RisingBD, 23 August 2014. 
on the floor [we were sitting in the guestroom of the hall]. I was thrown out of the campus for one year. Some other students are now suspended and they cannot come to the campus. (Senior BCL leader, A University)

The willingness to take risks ${ }^{48}$ was often a talking point with different student activists. In telling stories about their activities, the element of risk often cropped up. Risk was often equated with danger and the numerous problems you run into as part of your political activities. These risks and dangers were mostly considered in the context of violent interactions with rival student activists, often of a factional nature, as shown in the quote above. The risks were not simply a part of being politically active, as the ability to commit yourself during these risky times was considered a marker of a worthy student activist. The risk of being seriously injured or suspended from campus (as mentioned in the quote above), but also the risk of getting arrested or, in the worst instance, killed, provides a student leader with credibility and proves his commitment and value. Spilling one's blood makes one worthy.

This risk, of course, does not extend only to the time one is active on campus, engaged in factional violence; risk is also run when one's party is not in power. Indeed, student activists sometimes go underground if power changes hands at the central level.

We take a lot of risk. If the government changes in two years we are in all the lists of the police and the security services. We will not be able to find a job and whenever something [criminal] happens our name will be included in the list of suspects and perpetrators [and we risk being arrested]. (BCL cadre, A University)

Yet risk is not only a danger undertaken passively, regarded as something that is part of the student activist's life. We should be aware of what Caitlin Zaloom has called 'the productive life of risk'. ${ }^{49}$ Student leaders actively take risks and transform themselves in performative self-sacrificial acts. What was sacrifice in terms of national struggles (see above) is now emulated and renegotiated in terms of sacrifice for the party. ${ }^{50}$ Central to the conceptualization

${ }^{48}$ The interview above was conducted in English and the English word 'risk' was used. It usually translates in Bengali as jhuki (kora).

${ }^{49}$ Zaloom, C. (2004). The productive life of risk. Cultural Anthropology, 19(3), p. $3^{6} 5$.

${ }^{0}$ This is in relative contrast with the mastaans Ruud discusses. For them, discussing their 'self-sacrifice [...] they never said they were acting as representatives of political parties' (Ruud, The political bully, p. 318). This can potentially be explained by the 
of sacrifice in this context is what we would call 'victimhood'. To think this through in a comparative perspective, in discussions of communal violence, notions of sacrifice are mostly considered in the context of the act of sacrificing someone else, which brings a benefit-in the form of cleansing that person or the nation in general. ${ }^{51}$ Victims remain an almost passive element in the sacrificial act. In contrast, in Bangladesh, victimhood plays a crucial role in operationalizing sacrifice and is actively sought out, as it is valued in the Bangladesh political system. ${ }^{52}$ Although of a completely different nature, it is related to the way in which sacrifice is understood in the Naxalite movement in India-as a form of martyrdom for the political organization. ${ }^{53}$ In contrast to this-and although both Sheikh Mujibur Rahman and Ziaur Rahman are revered as martyrs (shahid) for their respective political movements ${ }^{54}$ — student activists do not seek violent death. $^{55}$

Moreover, the act of wounding or killing political opponents is not conceptualized as an act of sacrifice per se; rather, the victim can claim to have sacrificed for the party. It is as such that victimhood is valued in the context of sacrifice. The act of wounding and killing themselves are only a way to express or attain supremacy over opponents (very directly) but are not seen as sacrificial. This type of violent act falls into the category of 'risk', which is valued within student hierarchies. However, if perpetrators were to be punished for these acts of violence-from temporary expulsion from the campus to imprisonment - this can be instrumentalized as a form of self-sacrifice. As such, risk and sacrifice are closely related. Risk therefore contains the potential for (violent) self-sacrifice.

These sacrificial acts not only feature in speech acts, in the form of the many stories about student heroics, which are used to prove one's valour and loyalty to the party, but are also visually represented.

fact that his mastaan informants had become independent from their student political backgrounds, while mine were still fully invested in campus politics.

${ }^{51}$ For an excellent discussion, see: Peabody, Disciplining the body.

${ }^{52}$ See also: Andersen, Time-use, activism and the making of future, pp. 210-211.

${ }^{53}$ Suykens, B. (2010). Maoist martyrs: Remembering the revolution and its heroes in Naxalite propaganda (India). Terrorism and Political Violence, 22(3), pp. 378-393.

${ }^{54}$ Both were killed in coup attempts.

${ }^{55}$ As such, it should not come as surprise that student violence is less lethal than overall political violence in Bangladesh. Unwritten rules of engagement also mean that in most clashes less lethal weapons are used, including clubs (lathi, but also cricket bats) and different types of knives. Small arms are used, but mostly of poor quality, which also makes them less deadly. 
A genre of political posters uses exactly this iconography of risk and sacrifice to get across its message. Although the genre of political posters in Bangladesh-their iconography, use, and place-warrants a separate study, I do want to briefly discuss here an example of how these are used. ${ }^{56}$ Although Facebook has become a new public space where student leaders showcase both their connections and their loyalty to the party, political posters remain an effective way to publicize this commitment. Importantly, the most public statements, like the one presented below, are related to inter-party violence. This indicates that while self-sacrificial acts that result from intraparty violence are appreciated within a specific student hierarchy (see also below), inter-party violence has a different morality. Intraparty sacrifice, while crucial to securing a position within the student hierarchy, is not considered to speak to the same public morality, and this is reflected in different instances of political leaders publicly denouncing factional violence.

The poster under discussion presents Obaidul Haque Nasir (see Figure 1), then office secretary of the JCD Central Committee and a joint convener of the JCD Dhaka University Unit, in quite dramatic circumstances. As is usual in almost all political posters, a formal picture of Nasir is accompanied by smaller pictures of the (historical) party leadership, in this case the former Bangladesh president and BNP party founder Ziaur Rahman, his widow and current party president Khaleda Zia, and their son and current BNP vice-president Tareque Rahman. But two other, non-traditional photographs on the poster catch the eye. In the middle picture Nasir, wearing a bloodied singlet, is lying down with a bandage around his head; in the other he is sitting up, his eyes vacant, with blood streaming from a wound on his head.

The photographs were taken after Nasir (together with a large number of other high-ranking JCD leaders) was injured in an attack by BCL members, on Dhaka University campus in June 2010. ${ }^{57}$ While for Nasir himself this proved the brutality of the BCL, ${ }^{58}$ the action

\footnotetext{
${ }^{56}$ While still a marginal 'genre', more and more of these type of posters seem to be appearing, including from the AL.

${ }^{57}$ For more details, see: 25 hurt in BCL attack at DU. The Daily Star, 22 June 2010. This event came in the aftermath of another violent event - with both factional and inter-party elements coinciding — and in which JCD president Tuku was wounded. For details and an analysis, see: Andersen, Time-use, activism and the making of future, pp. 209-212.

${ }^{58}$ Interview with Obaidul Haque Nasir, September 2011.
} 


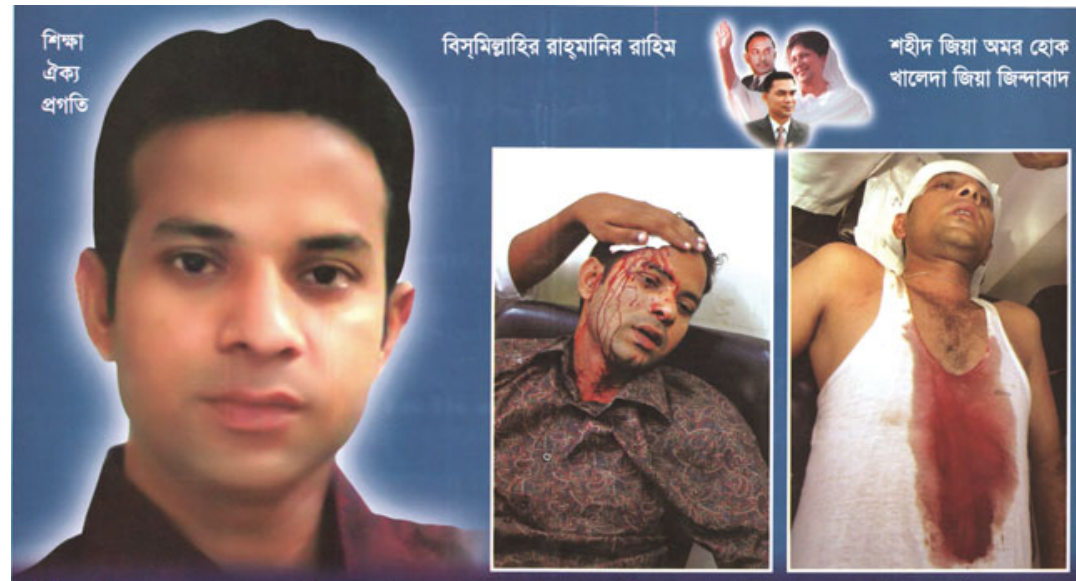

টাाাইল জেলার কৃতী সষ্তান আওয়ামী ফ্যাসিবাদের বির্দ্ধে প্রতিবাদী কষ্ঠস্বর্ন

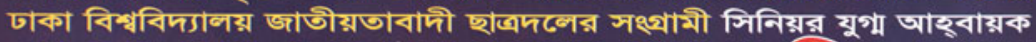

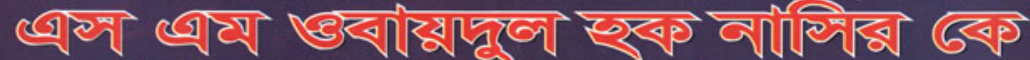

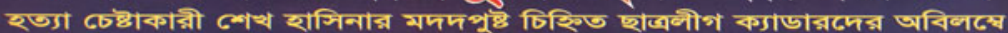

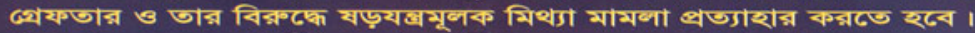

\section{বাংলাদেশ জাতীয়তাবাদী ছাতদল, টাঙ্গাই জেলা}

Figure 1. (Colour online) ' ... Obaidul Haque Nasir is a victim of attempted murder ...' Source: From the publicity campaign of Obaidul Haque Nasir.

itself was a performance of the commitment of the JCD leaders to the BNP cause and their willingness to sacrifice themselves for the party. The poster therefore becomes inscribed with an iconography of risk and sacrifice. As copies of these posters were pasted around the city headquarters of the BNP, the images visually represented not only the brutality of the JCD, but also the brutality of the sitting AL government. For Nasir himself, this poster was a clear statement of the risk he had taken, his commitment to sacrificing himself, and a tool with which to further his political career (for instance, when lobbying to be included in the soon-to-be-formed new JCD Central Committee).

In May 2012 Nasir was arrested for 'creating anarchy and obstructing policemen when discharging their duties 59 when protesting against the arrest of a large number of high-ranking BNP leaders, with regard to hartal violence, a case in which he is

${ }^{59}$ Moneruzzaman, M. Police preparing charges against BNP, alliance leaders for damaging bus. New Age, 7 May 201 2; 33 leaders of 18-party alliance sent to jail. The Independent, 17 May 2012. 
also implicated. He continues to court risk and get his name in the newspapers, thus showing his continued commitment to the party and its leadership - and of course carving a space for himself as a potential candidate for an interesting position when the BNP returns to power. His efforts seem to be paying off as he was appointed joint generalsecretary of the JCD Central Committee in September 2012.

This poster is possibly one of the most explicit examples of the use of self-sacrifice as a political tool by student leaders. Their willingness to take risks and, as a result, become visible to the party leadership is a crucial element in student violence. The performative nature of this violence and its role in showing commitment to the leadership is well illustrated by the following quote from a leader of the JCD, known to be involved in many violent clashes:

When a clash occurs we know beforehand that it will happen and one day in advance we warn our activists that an important program will take place. Then we clash, sometimes with the rival student group, often with our own and then the road clears. Some students are known to be courageous and like these clashes. They are well regarded by the leadership. (JCD leader, C University)

He first stresses the well-organized-almost staged-nature of the clashes, which are often considered spontaneous events. Secondly, his use of 'courageous ${ }^{60}$ denotes this same element of conscious risk-taking. Both elements were also crucial in Nasir's case. The participating JCD activists were very well aware that their presence on campus, with a large number of their leaders, would incite a (violent) reaction from the BCL. They were conscious that it would become highly visible proof of their commitment to BNP politics. The enactment of a violent clash, either with a rival student organization or with their own, becomes a decisive moment at which to become visible. The decision to be 'courageous', to risk (bodily) harm, is then approved of by the party leadership. ${ }^{61}$ Violence and the taking of risk establish a link between an individual student activist and the party leadership. As such, taking risks becomes a tool to show oneself off, to include oneself in the picture, and, through involvement in, often

\footnotetext{
${ }^{60}$ This interview was conducted in English.

${ }^{61}$ During field research in Dhaka in October 2015 Julian Kuttig was told that when some student activists submit their CV for a position in their respective student organizations they include an overview of their involvement in violent activities. Personal conversation with Julian Kuttig.
} 
violent, political activities, to gain a foothold in the party structure and thereby secure (future) access to the state.

However, what the example of Nasir also shows is that the most publicly instrumentalist performances of self-sacrifice might only be deployed by specific categories of student activists. It also allows the complication of the distinction between (everyday) risks and the public performativity of sacrifice. While the data do not allow one to make conclusive statements about this distinction, I would argue that the need to take risks and behave violently is most common among lowerand mid-level leaders. Again returning to the issue of publics, the violent performances of mid-level leaders are mostly directed towards their direct patron, usually another mid-level or senior leader on the campus. Their ability to directly engage in violence and take the necessary risks-be 'courageous'-makes them highly valuable to a leader who needs to be able to control violence to help buttress his own position on campus. However, for more senior leaders, and certainly those looking for a career in party politics, the ability to control violence, rather than use it directly, is central. Their publics are party political patrons looking for reliable conduits for patronage on campus.

When we turn to sacrifice, however, the dynamics are rather different. While lower level activists do undertake self-sacrificial acts-by getting wounded, expelled, or arrested-this type of sacrificial performance is often instrumentalized by more senior leaders. It is these leaders who publicly use their self-sacrifice as a way to show their commitment. As the example of the poster shows, they actually seek out a stage to perform sacrifice. Finally, the most publicized types of self-sacrifice seem to be viable predominantly after inter-party violence. While self-sacrifice in intra-party violence was spoken about positively by student respondents, they lacked the public morality necessary to display them in iconographies of victimhood.

\section{Violence and access to the party-state}

You want to know about student politics (chhatro rajniti)? It used to be politics (rajniti), but now the ethics (niti) have gone [and only kingdom/rule (raj) remains]. ('Non-political' hall resident, A University)

The value of a student leader is their usefulness to both political parties and individual politicians. Student leaders' main worth lies 
in 'their skills in organising processions or meetings' (JCD leader, B University) and in their ability, if necessary, to violently engage rival party activists or, when in opposition, the police. By taking risks, student activists can show both their commitment to the party and that they are to be trusted. As the quote above indicates, for many students this has resulted in the loss of the moral high ground within the student movement, as their main aim is perceived to be to gain access to the state, the main centre of rule.

Indeed, those student leaders who have gained a position within the ruling party's student organization, as a hall or campus committee member, gain privileged access to the protection of the party in power. Such a position can only be reached when one is able to show the power of one's particular faction through clashes with other factions or, when one's power has been established, by controlling and limiting violence on campus. Given the party-state nature of Bangladesh's political organization, this means they get privileged access to state resources.

If successful, student leaders can benefit from party-state patronage both during and after their time at university. In this sense student violence is, to use Ward Berenschot's phrase, a form of maintaining relations. ${ }^{62}$ First, there are very direct benefits of patronage relations with the party-state. Respondents from A University, where factional clashes frequently occurred because there was no campus BCL committee and therefore no clear hierarchy in campus politics, reflected on this. The clear-cut authority that committee membership provides, allows the use of protection through patronage relations with the central party-state leadership. This entails private accumulation for such students as well as the ability to distribute spoils to supporters.

At the moment there is no committee, so it is difficult to get money. But after the committee is formed the money can come back. You know, from tender money is collected. It is the system. We try to be good, but we cannot change the system. (Senior BCL leader, A University)

Or,

Normally the students' organization gets a cut for tender for a large development. But now there is no committee so this does not happen. But when a new committee is formed this will start again. (Middle-level BCL activist, A University)

${ }^{62}$ Berenschot, W. (2009). Rioting as maintaining relations: Hindu-Muslim violence and political mediation in Gujarat, India. Civil Wars, 11 (4), pp. 414-433. 
While a discussion of different types of money-collection would take us too far here, ${ }^{63}$ the connection with the party-state not only offers protection for the student money-collectors, it also makes them into a potential source of protection. The cut in the tender process is often the result of a service rendered in terms of making sure a specific contractor wins the tender. In University A the absence of a committee made it difficult to ensure viable protection to contractors, exactly because the link with the party-state was unsure, if not absent. Gaining access to the committee, through engaging in performative violence, thus becomes a crucial element in gaining access to the state, which in turn is important in collecting benefits while a student.

In the longer run, having been a member of the committee, at the hall or the university level, will bring benefits in the form of a political career, for example, or access to a government job. Some student leaders aspire to a political career. Like Nasir, whom we discussed in the previous section, this means coming through the ranks of the different organizations connected to the political parties. In each of these positions, specific tasks have to be performed and particular roles are deemed appropriate. As mentioned above, a capacity for violence is considered a normal part of student organizations.

I have ambition to continue in politics. I am an Awami League supporter. So now I am in BCL, but afterwards I will go in Jubo League and maybe later Awami League. I want to become an MP. Getting money is not difficult. I will get it from some well-wishers and the party will give it. (Middle-level BCL activist, A University)

An ambition to become an MP is of course the most obvious reason why one aspires to a leadership position in student politics. While this is too lofty an ambition for most, they might instead seek to become important players in more localized political networks, maybe as a union chairman or with a position on the district party board. While a violent image might be difficult to shed if one is after a ticket as an MP, a capacity for violence remains a valuable asset in many lower-level party positions. For the large number of student activists who are not able to reach the highest level within university campus politics, political activism still enables them to embed themselves in crucial patronage networks necessary after they finish their university education. Again, more research should be conducted on whether specific class positions within the political student body make it

\footnotetext{
${ }^{63}$ See also: Ruud, The political bully.
} 
necessary for some to deploy violence to broker the necessary networks (which will help one to get a position within a government institution, whether it is a ministry, the administration, the police or a parastatal). While the resulting politicization of government jobs is sometimes lamented, ${ }^{64}$ they are heavily coveted by student activists and provide a reliable source of income when one's party is in power:

There is a lot of unemployment [in Bangladesh]; so student politics is a way to gain a job later and get a good income. (JCD leader, C University)

At first sight the Bangladesh state has only limited capacity to provide jobs and opportunities directly to university graduates, in contrast to what is considered burgeoning private and NGO sectors. Although the public sector in Bangladesh only provides about four per cent of employment, ${ }^{65}$ it provides almost 20 per cent of salaried employment. Wages are substantially higher than those in the NGO and private sectors, with hours worked similar to the NGO sector, but substantially lower than in the private sector. Moreover, with an average of 10.7 years of education, the public sector employs substantially more people with higher education than the salaried private sector. ${ }^{66}$ Combined with poverty rates among those employed in the public sector being half of those in the NGO sector and a third of those in the private sector, public sector jobs remain a scarce but nonetheless attractive proposition for university graduates and thus also student activists. Moreover, the networks of the party-state do not simply extend themselves to the public sector. In addition, the right political networks might help one to access jobs and resources in business circles. As Arild Ruud has shown, some violent student activists transform into mastaans, using their links with student organizations to gain political protection. ${ }^{67}$

Although we have mentioned that a very violent image might be an impediment rather than an asset to aspiring party political leaders and that, because of this, organizing, rather than actively participating in violent actions, might help student leaders to further their career in party politics, this is not always the case. Public knowledge about

${ }^{64}$ Jahan, F. (2006). Public administration in Bangladesh. Dhaka: Centre for Governance Studies, BRAC University.

${ }^{65}$ The NGO sector also provides four per cent of employment, and the private sector 14 per cent. Paci, P. and Sasin, M. (2008). Making work pay in Bangladesh: Employment, growth, and poverty reduction. Washington DC: World Bank.

${ }^{66}$ Ibid., p. 28.

${ }^{67}$ Ruud, The political bully, p. 308. 
the violent activities of (former) student leaders does not always seem to hamper their political careers. The disappearance, during my fieldwork on student politics, of Ilias Ali, a well-known former student leader, active in the 1980 os (for example, during the antiErshad movements), former MP, and organizing secretary of the BNP, has made this very clear.

[C]ertain quarters have been putting up a poster all over town, depicting Ilias as a terrorist $[\ldots]$ This poster aims at tarnishing Ilias' image $[\ldots]$ Ilias Ali was a student leader, leader of Chhatra Dal, while studying at Dhaka University in the eighties [...] They had several bloody clashes over inhouse feuds [...] It is no secret that at that time Awami Chhatra League, JSD [Jatiyo Samajtantrik Dal (National Socialist Party)] [...] and the other student fronts all had armed cadres [...] So the people are not fooled by this attempt to single out Ilias Ali as a criminal [...] He had left student cadre politics and had joined mainstream BNP. He had shrugged off any negative image he may have had in the past and became a national level leader. ${ }^{68}$

In this quote, it is not the mention of Ali's violent past that was resented, but the fact that he was 'singled out'. What he did as a student leader was, in fact, the norm, and people should not, by calling him a terrorist or a criminal, have denied this normalcy. The image of a violent student leader then appears not as an anomaly, but as the norm-something that is 'no secret'. One can be redeemed and shrug off the 'negative image'. By coming through the political school, as the student in a previous quote mentioned, of first student organization, then youth (jubo) organization, and, finally, full political party stature, one can leave behind the necessary violence of 'bloody clashes' and become a respected political leader. 'A hundred percent good man cannot do politics', ${ }^{69}$ but the necessary wickedness associated with violence can be overcome through careful growth within the party ranks. Violence might be necessary at an early stage of one's political career, but it should not tarnish one's image as a political leader later.

\section{Conclusion}

In Bangladesh student politics, violence plays a crucial role in establishing public authority. Violence and political patronage are

\footnotetext{
${ }^{68}$ Poster maligns Ilias Ali. Probe News Magazine, 11 June 2012.

${ }^{69}$ Interview with a senior BCL leader, University A.
} 
recursively constituted. ${ }^{70}$ A talent for (performative) violence makes one a good target for political protection, and the ability to violently maintain one's authority is enhanced by political protection. As this entails a privileged relationship with what I have called the partystate, violence and state protection feed off each other. Given that student leaders and activists are willing to perform sacrificial acts to gain access to party-state patronage, we should not consider student violence as a sign of growing state fragility. What we see in Bangladesh is a particular state form - the party-state-which remains the central focus of rule-making and governance.

Violence is an integral element of party-state rule, as it is used to decide on hierarchies within the student body. As a result, student violence is productive, in the sense that it not only signals potential worth to political patrons, but also because it aims at cementing these privileged relationships. The capacity for violence has to be continuously maintained and affirmed, but at the same time it is also supported by state protection. As such there is a constant interplay between student activists and state patrons, in which violence plays a central role. Political parties are often called upon by the media to control (the violence of) their student organizations. But if student violence indeed operates in the way that I have argued here, controlling student organizations and their violence goes against the interests of senior party politicians.

While we should not condone student violence, it is not simply criminal. Violence plays a crucial role in the political organization of Bangladesh. Passing through the political channels, from student leader to mid-level organizer, one can, like Ilias Ali, become a politician. Or one can gain a good position within the political administration. The willingness to take risks and perform selfsacrificial acts, and also bear the brunt of those choices when one's party is not in power, proves one's worth.

In the literature on communal violence, sacrifice is something unexpected and those sacrificed are unlucky victims; however, in Bangladesh student politics we see self-conscious self-sacrifice. Victimhood can be transformed into political capital, translating sometimes into veritable iconographies of injury. Running certain risks is part of the student politician's habitus. It is highly ambiguous,

\footnotetext{
${ }^{70}$ This term is inspired by the 'recursive constitution' of property and power as conceptualized by Sikor, T. and Lund, C. (2009). Access and property: A question of power and authority. Development and Change, 40(1), p. 2.
} 
is a constant presence, as one can always be attacked by rivals, and it makes student politics dangerous. But violence can also be sought out, as being courageous and taking risks is highly appreciated within student hierarchies.

Moreover, in research conducted in (North) India, muscular politics has been considered as something that appeals to certain broad polities. Lucia Michelutti has discussed how goonda-style politics has become associated with Yadav political assertion which provides legitimacy among the wider public. ${ }^{71}$ This type of muscular legitimacy remains fairly weak within the broader Bangladesh student community, where most students would consider student violence in negative terms. Muscular politics remains mainly for internal consumption, within student-political and party-political networks, and is not addressed to a wider audience. As a result, this article argues that muscular student politics is part of an internal partypolitical repertoire in which authority is produced within party political networks, while (more naked) power is geared towards a more general public. The latter's response remains under-studied, but could be understood as a form of complicity with the party-state tactics of government, rather than a full endorsement of such violent tactics (as discussed in the work of Lisa Wedeen on Syria $\left.{ }^{72}\right){ }^{73}$

Finally, this points towards the limits of student public authority, which is greatly circumscribed, partly because it ultimately rests on party-political patronage. Successful student leaders are indeed able to become public authority figures on Bangladesh campuses by becoming conduits of patronage through the performance of violent sacrifice and they are able to extend this authority in a wider public sphere, by providing protection to (illegal) markets or to contenders for tender. Yet this authority is highly time-limited-as long as one's party remains in power-and the legitimacy of their rule is always contested. Still, student public authority should always be considered in relation to its uses for party-state rule, and its 'public' ${ }^{74}$ has, in the

\footnotetext{
${ }^{71}$ Michelutti, Kingship without kings.

${ }^{72}$ Wedeen, L. (1998). Acting 'as if': Symbolic politics and social control in Syria. Comparative Studies in Society and History, 40(3), pp. 503-523.

${ }^{73}$ For an interesting take on the question of the legitimacy of goonda politicians and the role of morality, which could also inspire research on Bangladesh, see: Piliavsky, A. and Sbriccoli, T. (2016). The ethics of efficacy in North India's goonda raj (rule of toughs). Journal of the Royal Anthropological Institute, 22(2), pp. 373-391.

${ }^{74}$ See also: Hansen, T. B. 'Whose public, whose authority? Reflections on the moral force of violence' in this special issue.
} 
current democratic phase, shrunk as a result of the changing rationale of sacrificial violence, now not in support of the nation, but rather for the good of party-state rule.

Recent political developments in Bangladesh continue to necessitate close attention to the dynamics of student politics. Given that opposition student activists banked on regaining power after the next elections, it remains to be seen how the ability of AL to run two consecutive governments (2008-2019(?)) will affect the rationale of inter-party violence. If opposition becomes a permanent condition and future benefits are foreclosed, how will this affect the sacrifices opposition student activist are willing to make for their party? Moreover, if, as some of my Bangladesh friends maintain, AL continues to stay in power (indefinitely), will this make factional clashes even more crucial, given the ever-closer integration of party and state? Violence as a means of settling hierarchies has become normalized to such an extent, with clashes involving members of political parties occurring on an almost daily basis, that the consolidation of power we currently see will probably not mean the end of political violence-not on Bangladesh's campuses, and also not beyond them. 